\title{
Original article:
}

Investigating antemortem, perimortem and postmortem injuries: forensic implication Jaiyeoba-Ojigho Jennifer Efe, ${ }^{1}$ Odokuma Emmanuel Igho, ${ }^{2}$ Umukoro Joysour Mamuyovwi ${ }^{3}$

Abstract:

Context:Skeletal injuries discovered from human remains are classified into antemortem, perimortem and postmortem. Studies that documents injuries of various skeletal elements is of vital importance to forensic anthropologist. Aim: This study investigated antemortem, perimortem, postmortem and other injuries caused by various instruments among skeletal elements. Methodology: A total of 200 bones of unknown age and gender were studied. Injuries were interpreted based on basic features specific to them and each was described and photographed. Chisquare test was used to show association between skeletal elements and time of injuries. Statistical evaluation was done using SPSS 20 Software Version. Significance was accepted at $\mathrm{p}<0.05$. Result: The bones from this study showed $17.50 \%$ antemortem, $24 \%$ perimortemand $57 \%$ postmortem. Findings showed that $49.50 \%$ of the bones had blunt force injury, $30.50 \%$ had sharp force while $20.00 \%$ had ballistic injuries. Basic features of antemortem injuries were smooth and round fractured edges within bones. Sharp, smooth fractured edges were observed among perimortem bones in contrast to irregular, blunt fractured edges and uneven discoloration in postmortem bones .Straight line incisions were seen in bones with sharp force injuries, presence of an entrance wound in ballistic injuries while an impact area was discovered in most bones with blunt force injury.Findings showed that there exist a significant association between ante, peri and postmortem injuries in the ulnar,radius and femur bones $\left(\mathrm{X}^{2}=25.32 ; 13.35 ; 10.11 . \mathrm{p}=0.000 ; 0.001,0.006\right)$ Conclusion: Bones from this study showed more post mortem blunt force injury.

Kevwords: Antemortem; Perimortem; Postmortem; Skeletal injuries; Bones

Bangladesh Journal of Medical Science Vol. 20 No. 01 January'21. Page : 50-57 DOI: https://doi.org/10.3329/bjms.v20i1.50345

\section{Introduction:}

Bone have been defined as a complex material that constitute both organic (mostly collagen) and mineral components which has been mainly identified as hydroxyapatite . ${ }^{1}$ it has been reported that the hydroxyapatite gives bone its hardness and rigidity, while collagen is a connective tissue that provides bone its elasticity and flexibility. ${ }^{1-4}$ Bone had also been described as been viscoelastic and anisotropic. . $^{5-}$ ${ }^{6}$ According to Hiller et al. (2003) the two main types of bone tissue are cortical and cancellous. ${ }^{3}$ Cortical bone has been described as the hard hollow cylinder of the bone, responsible for mechanical stability while the cancellous bone as the spongy interior of the cylinder responsible for nutrient storage and transport. ${ }^{3}$

Investigating skeletal injuries and its possible connection with the time and cause of death have been highly imperative in forensic anthropology. ${ }^{7}$ Skeletal injuries are classified into cranial and precranial categories based on their position but a different classification system was linked with the time and nature of injuries. ${ }^{1,7-8}$ According to some authors, injuries to bones can occur before death (antemortem) ,at or near the time of death (perimortem) or after death (postmortem) describing the time of occurrence. ${ }^{9-10}$

1. Jaiyeoba-Ojigho Jennifer Efe

2. Odokuma Emmanuel Igho

3. Umukoro Joysour Mamuyovwi

Department of Human Anatomy and Cell Biology, Faculty of Basic Medical Sciences. Delta State University, Abraka, Delta State, Nigeria.

Correspondence to: Jaiyeoba-Ojigho Jennifer Efe, Department of Human Anatomy and Cell Biology, Faculty of Basic Medical Sciences and Delta State University, Abraka, Delta State, Nigeria. Email: efemenaojigho@gmail.com 
Injuries present in bones have also been identified as blunt force, sharp force, ballistic and thermal injuries depending on the instruments that caused death and their nature on bones. ${ }^{1}$ Scrutinizing injuries in relation to death have been of vital importance to forensic anthropologist providing clues on lifestyles, health, norms and culture of an individual or group of people because they first identify these injuries, determine the relative time at which they were produced and the techniques responsible for their formation. ${ }^{1-2,8}$ Spitz et al.(2006) detailed that blunt force trauma was the most frequent type of injury observed during autopsy and the head was the most quotidian location,especially in homicides. ${ }^{11}$

A series of different techniques such as macroscopic and microscopic examination of skeletal elements had been used in investigating injuries or trauma. ${ }^{12}$ Macroscopic examination used by several authors and forensic anthroplogists have involved the observation of fractured patterns ,fractured edges, bone tear, osteogenic reactions and adherent materials found within bones, ${ }^{1,8}$ while microscopic analysis have been useful as it allowed the observation of bone fracture characteristics, hair and residues of other materials such as metal found within bones.? According to Symes et al. (2012) low magnification (Power $\times 3-40$ ) with a stereoscope is recommended forinquiries from multiple blows or tool impressions. ${ }^{12}$ The use of medical imaging had also increased in the investigation of skeletal remains with Dedouit et al.(2014) carrying out a study on visual anthropology and forensic identification using a multidetector CT. ${ }^{13}$ Knowledge on injuries or trauma among skeletal elements in Nigeria are limited, hence this study investigated injuries in relation to the time of death and the nature of injuries caused by various instruments among skeletal elements. The study also aimed at examining the association between skeletal elements and the time of injuries.

\section{Methodology:}

The study was a descriptive crosssectional study. The work described injuries in relation to death and the nature of injuries or trauma found within bones. A total of 200 bones of unknown age and sex were obtained from Anatomy museum and the gross laboratory of Delta State University, Abraka, Delta State, Nigeria. The bones were sorted into calvariums, skulls, long bones and short bones. Antemortem, postmortem and perimortem injuries were interpreted based on fracture patterns, fracture edges,bone tear, plastic deformation, adherent materials found within investigated bones. Other injuries such as ballistic, sharp force, blunt force and thermal injuries were explained based on basic features specific to them and each was described and photographed.

Data was represented in frequencies, mean and tables to show distribution of types of injuries.Chisquare test was used to show association between skeletal elements and time of injuries. Statistical evaluation was done using SPSS 20 Software Version. Significance was accepted at $\mathrm{P}<0.05$.

Ethical clearance: Ethical consent was sourced from the Research and Ethics Committee of the Faculty of Basic Medical Sciences, Delta State University, Abraka, Delta State, Nigeria on the $14^{\text {th }}$ day of August, 2018 with a reference number DELSU/ CHS/ANA/18/13.

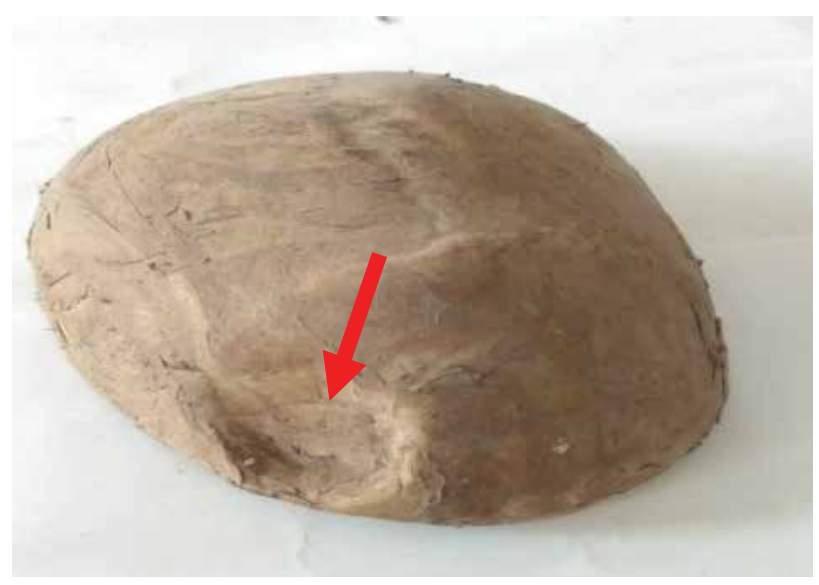

Fig 1: Calvarium showing antemortem injury

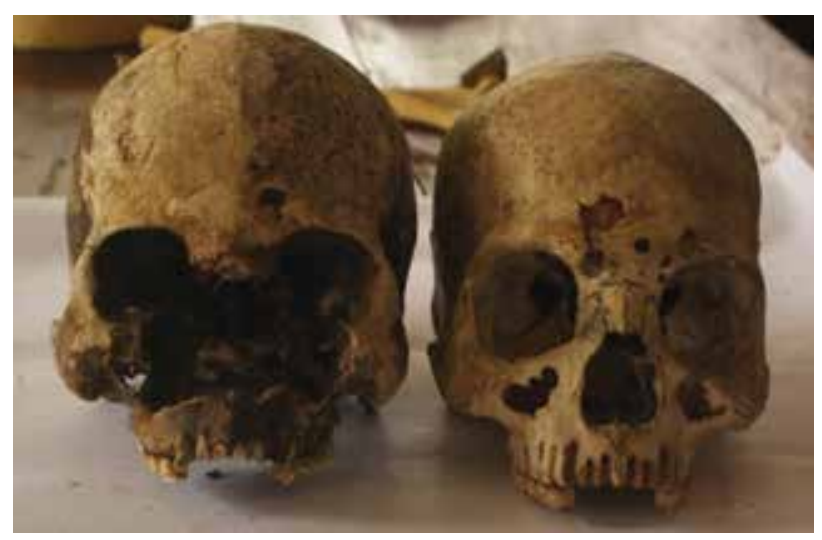

Fig 2: Skulls showing blunt force injury to head and face 

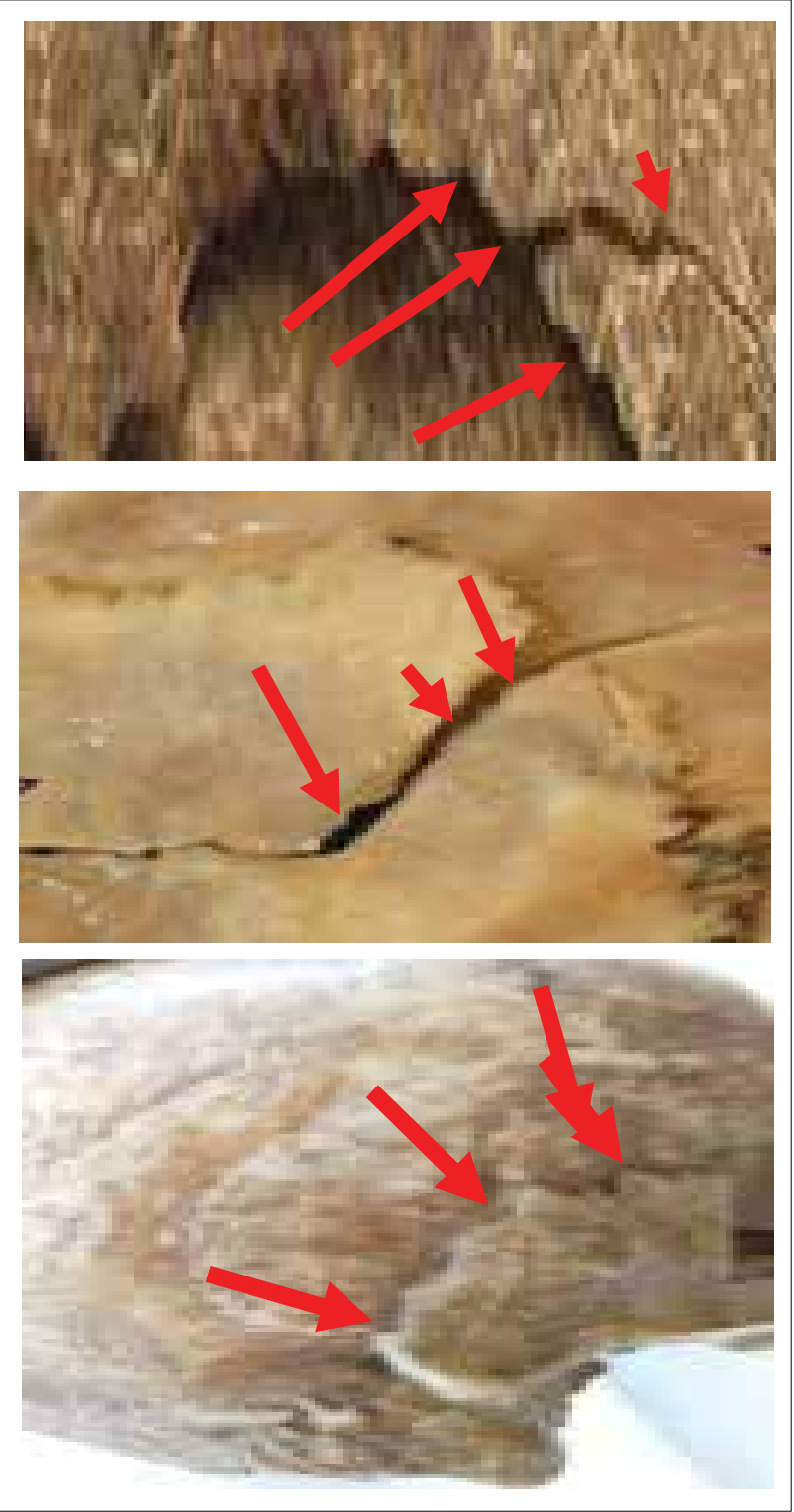

Fig3:Skulls showing perimortem injuries

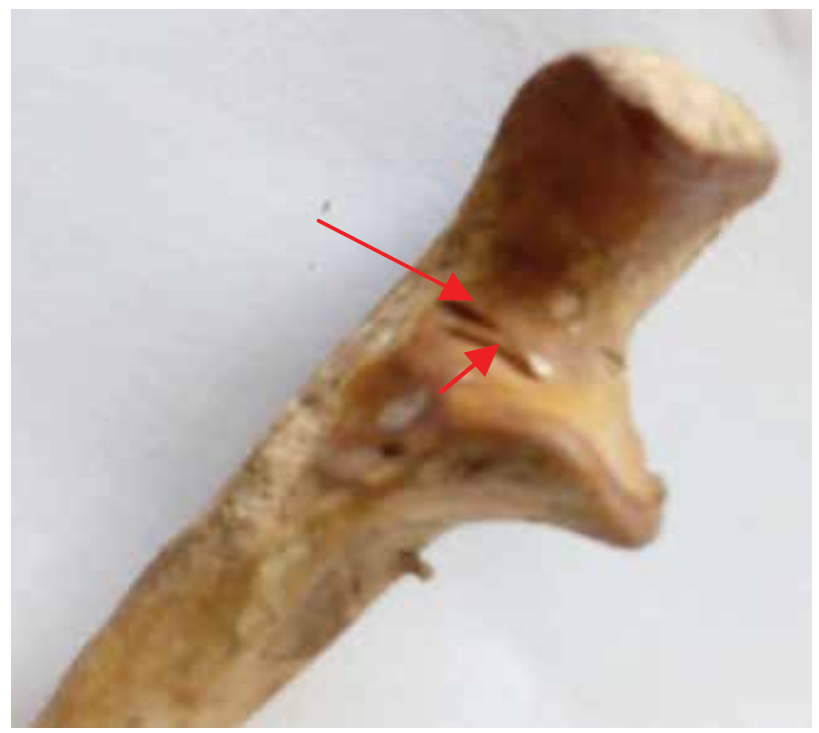

Fig 4: Ulnar bone showing sharp force injury

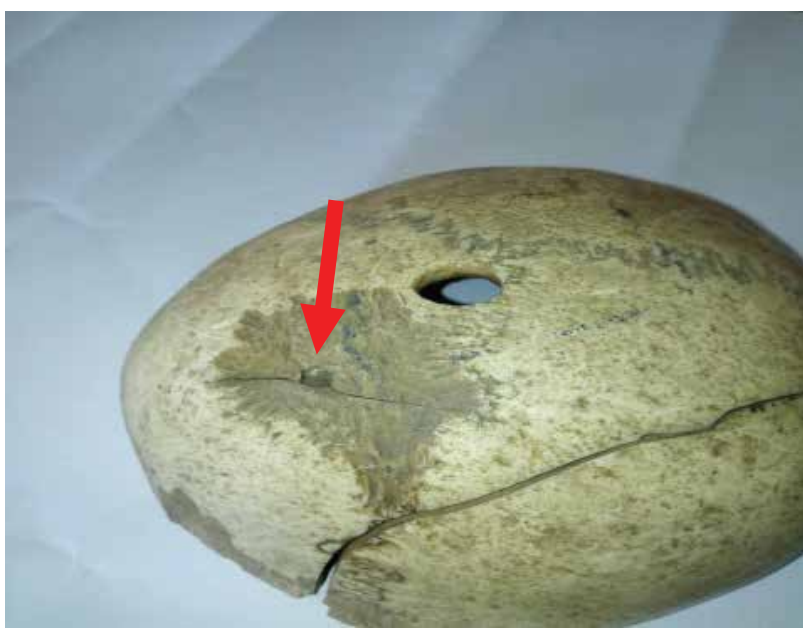

Fig 5: Ballistic injury showing an entrance wound

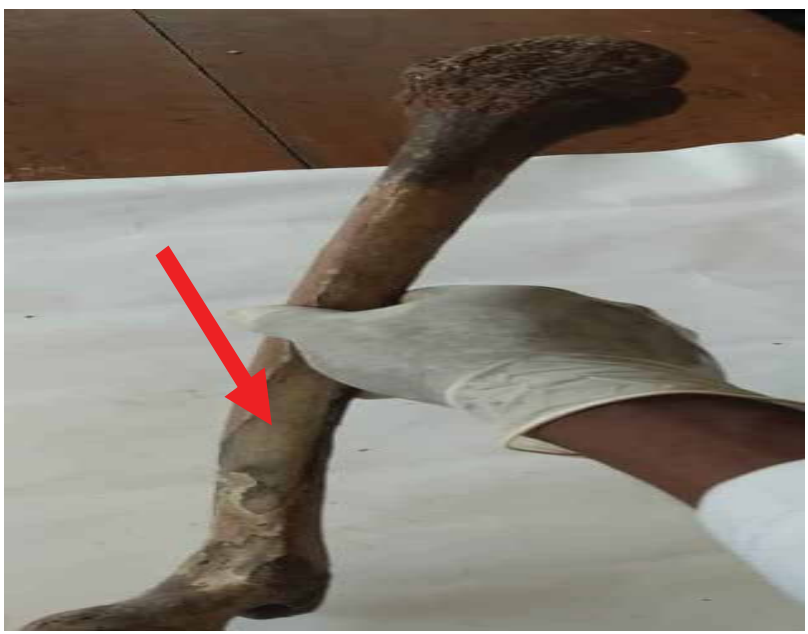

Fig 6: Femur bone showing an area of delamination in perimortem injury

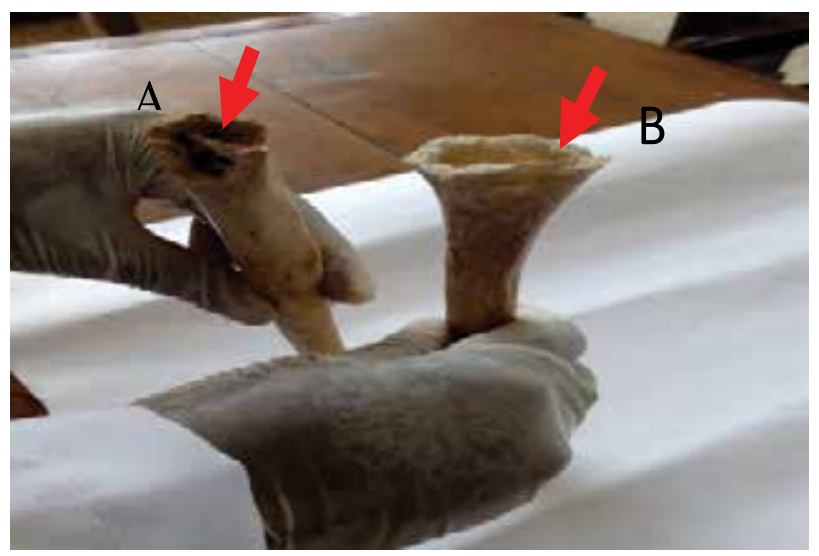

Fig 7: Bones showing fracture differences (A) aperimortem fracture depicting breakage at an acute angle with sharp fracture edges and (B) a postmortem fracture showing breakage at nearly right angles with blunt fracture edges 


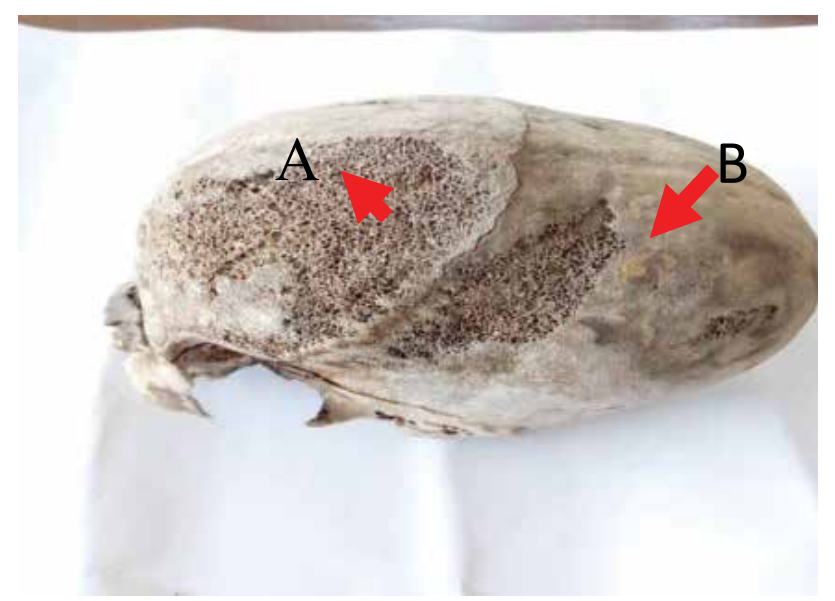

Fig 8: Skull showing (A) cancellous and (B) cortical bone

Table 1 : Percentage distribution of time of injury

\begin{tabular}{|l|l|l|}
\hline Time of injury & Frequency & Percentage \\
\hline Antemortem & 35 & 17.50 \\
\hline Perimortem & 48 & 24.00 \\
\hline Postmortem & 114 & 57.00 \\
\hline Nil & 3 & 1.50 \\
\hline Total & 200 & 100.00 \\
\hline
\end{tabular}

Table 2: Percentage Frequency Distribution of Nature of Injury

\begin{tabular}{|l|l|l|}
\hline Nature of injuries & Frequency & Percentage (\%) \\
\hline Sharp force & 61 & 30.50 \\
\hline Blunt force & 99 & 49.50 \\
\hline Ballistic & 40 & 20.00 \\
\hline Thermal & 0 & 00.00 \\
\hline Total & 200 & 100.00 \\
\hline
\end{tabular}

Table 3: Percentage Frequency Distribution of

\section{Time of Injury of various Skeletal Elements}

\begin{tabular}{|c|c|c|c|}
\hline $\begin{array}{c}\text { Skeletal } \\
\text { Elements }\end{array}$ & Time of Injury & Frequency & Percent \\
\hline \multirow{4}{*}{ Calvariums } & Antemortem & 3 & 13.6 \\
\cline { 2 - 4 } & Perimortem & 6 & 27.3 \\
\cline { 2 - 4 } & Postmortem & 10 & 45.5 \\
\cline { 2 - 4 } & Nil & 3 & 13.6 \\
\cline { 2 - 4 } & Total & $\mathbf{2 2}$ & $\mathbf{1 0 0 . 0}$ \\
\hline \multirow{4}{*}{ Skull } & Antemortem & 3 & 23.1 \\
\cline { 2 - 4 } & Perimortem & 3 & 23.1 \\
\cline { 2 - 4 } & Postmortem & 7 & 53.8 \\
\cline { 2 - 4 } & Total & 13 & 100.0 \\
\hline
\end{tabular}

\begin{tabular}{|c|c|c|c|}
\hline $\begin{array}{c}\text { Skeletal } \\
\text { Elements }\end{array}$ & Time of Injury & Frequency & Percent \\
\hline \multirow{4}{*}{ Ulnar } & Antemortem & 3 & 7.9 \\
\cline { 2 - 4 } & Perimortem & 8 & 21.1 \\
\cline { 2 - 4 } & Postmortem & 27 & 71.1 \\
\cline { 2 - 4 } & Total & $\mathbf{3 8}$ & $\mathbf{1 0 0 . 0}$ \\
\hline \multirow{4}{*}{ Radius } & Antemortem & 9 & 19.6 \\
\cline { 2 - 4 } & Perimortem & 10 & 21.7 \\
\cline { 2 - 4 } & Postmortem & 27 & 58.7 \\
\cline { 2 - 4 } & Total & $\mathbf{4 6}$ & $\mathbf{1 0 0 . 0}$ \\
\hline \multirow{4}{*}{ Femur } & Antemortem & 12 & 22.2 \\
\cline { 2 - 4 } & Perimortem & 13 & 24.1 \\
\cline { 2 - 4 } & Postmortem & 29 & 53.7 \\
\cline { 2 - 4 } & Total & $\mathbf{5 4}$ & $\mathbf{1 0 0 . 0}$ \\
\hline \multirow{5}{*}{ Pelvis } & Antemortem & 5 & 18.5 \\
\cline { 2 - 4 } & Perimortem & 8 & 29.6 \\
\cline { 2 - 4 } & Postmortem & 14 & 51.9 \\
\cline { 2 - 4 } & Total & $\mathbf{2 7}$ & $\mathbf{1 0 0 . 0}$ \\
\hline
\end{tabular}

Fig 1 to 9 illustrates some of the injuries observed among investigated bones from the Anatomy museum and gross laboratory of Delta State University, Abraka, Delta State, Nigeria. Table 1 showed that a total of 200 bones were investigated of which $57 \%$ were with postmortem, $24 \%$ perimortem and $17.50 \%$ withantemortem injuries. Table 2 presented percentage of the nature of injuries found within investigated bones. Findings showed that $49.50 \%$ of the bones had blunt force, $30.50 \%$ had sharp force while $20.00 \%$ had ballistic injuries. Table 3 showed specific bones that were observed for antemortem, perimortem and postmortem injuries. It reported 22 calvaria, 13 skull, 38 ulnar, 46 radius, 54 femur and 27 pelvic bones investigated.We observed $13.60 \%$ antemortem , 27.30\% perimortem and $45.5 \%$ postmortem injuries found within the calvaria, while $23.10 \%$ each antemortem and postmortem alongside $53.80 \%$ postmortem injuries noticed among the skulls (table 3 ).

Further findings reported $7.90 \%$ antemortem, $21.10 \%$ perimortem and $71.10 \%$ postmortem injuries discovered within the ulnar bones while the radiaa bones presented $19.60 \%$ antemortem, $21.70 \%$ perimortem and $58.70 \%$ postmortem injuries (table 3). The femur and pelvic bones reported $22.20 \%$ and $18.50 \%$ antemortem, $24.10 \%$ and $29.60 \%$ perimortemalongside $53.70 \%$ and $51.90 \%$ postmortem injuries (table 3 ). Table 4 explained an association between skeletal elements and injuries in relation to death. Chisquare test showed that the ulnar 
Table 4: Association Between the various Skeletal Elements and time of injury

\begin{tabular}{|c|c|c|c|c|c|c|}
\hline & \multicolumn{4}{|c|}{ Time of Injury } & \multirow{2}{*}{ Chi-Square } & \multirow{2}{*}{ P-value } \\
\hline $\begin{array}{l}\text { Skeletal } \\
\text { Elements }\end{array}$ & Antemortem & Perimortem & Postmortem & Nil & & \\
\hline Calvarium & $3(13.64 \%)$ & $6(27.27 \%)$ & $10(45.45 \%)$ & $3(13.64)$ & 6.00 & 0.112 \\
\hline Skull & $3(23.08 \%)$ & $3(23.08 \%)$ & $7(53.84 \%)$ & - & 2.46 & 0.292 \\
\hline Ulnar & $3(7.90 \%)$ & $8(21.05 \%)$ & $27(71.05 \%)$ & - & 25.32 & $0.000^{*}$ \\
\hline Radius & $9(19.56 \%)$ & $10(21.74 \%)$ & $27(58.70 \%)$ & - & 13.35 & $0.001 *$ \\
\hline Femur & $12(22.22 \%)$ & $13(24.07 \%)$ & $29(53.70 \%)$ & - & 10.11 & $0.006^{*}$ \\
\hline Pelvis & $5(18.52 \%)$ & $8(29.63 \%)$ & $14(51.85 \%)$ & - & 4.67 & 0.097 \\
\hline Total & $35(17.50 \%)$ & $48(24.00 \%)$ & $114(57.00 \%)$ & $3(1.50 \%)$ & & \\
\hline
\end{tabular}

*Indicated statistical significant association between skeletal element and the time of injury

radius and femur bones had a significant association with the time of injury at $\mathrm{p}<0.05$.

\section{Discussion:}

Features of antemortem injuries observed from this investigation were the presence of an impact area, rounding and porosity near the fractured edges. Observation was similar to that of Sauer (1984);Aufderheid\&Rodrigueze (1998) and Byers (2005). ${ }^{14-16}$ According to Byers (2005), porosity near the fractured end is an indication of antemortem injury designating bone activity, reabsoption and fracture healing. ${ }^{16}$ Several authors had also reported that the second feature seen among skeletal elements was the slight rounding or remodelling of the fractured edges, indicating that the injury happened at least 7 days prior to death. ${ }^{8,14-16}$ Sauer , (1998) quoted an investigation done by Sledzik and Kellyon on the cranium of 257 America civil war victims, where osseous remodeling was observed 1 week after injury. ${ }^{8}$ Rounding of fracturededges in antemortem injuries have been associated with bone repair and healing. ${ }^{17,18}$ According to Kostantinos\&Chara, (2006) the basic attribute of antemortem injuries has been the presence of an osteogenic reaction that can be detected macroscopically, radiographically or histologically. ${ }^{17}$ In a study carried out among 127 cranial of America civil war victims for antemortem trauma in form of osteoblastic and osteoclastic signs with lines of demarcation, an osteoclastic reaction was reported 5days prior to injury while both osteoblastic and osteoclastic response was discovered among all victims 6 weeks after injury. ${ }^{18}$

From this study, evidence of perimortem and postmortem injuries observed among skeletal elements were the presence of specific fractured angles and edges perculiar to perimortem and postmortem injuries. Villa and Mahieu ,(1991) defined a fractured angle as the angle formed by the fractured and cortical bone surface while a fractured edge was described as the structure of the fractured margin. ${ }^{19}$ Further findings from this study revealed acute angles among perimortem bones while right angles were noticed among post-mortem bones. Sharp, smooth fractured edges were also observed among perimortem bones in contrast to irregular and blunt fractured edges alongside uneven discoloration in postmortem bones. Findings were not different from a study carried out by Bonnichsen (1979). ${ }^{20}$ According to his study among 88 fractures, $88.68 \%$ of the perimortem fractures presented oblique or acute angles while $73.68 \%$ of the postmortem fractures showed right discontinuity angles. ${ }^{20}$ Findings from this study was also in concordance with previous reports by Villa and Mahieu,(1991); Quatrehomme,(1997); Walker,,(2001) while it was in contrast with Marshhall,(1989) and White,(1992) who reported flaked fractures and bone peeling as indicators for perimortem injuries. ${ }^{19,21-24}$

Plastic deformation was present among some of the studied perimortem bones while broken fragments were attached to some of the skulls. Reports were not different from Jordana et al. (2013). ${ }^{25}$ Perimortem trauma on bones have been explained based on the periosteum and other soft tissues present at the time of fracture and when dried, they split with little fragments connected to each other. ${ }^{9}$ Several authors reported that wet bone has the capacity to undergo plastic deformation before been fractured than dry bone because of the collagen and moisture 
component which makes it flexible and resistant to tension. . $^{5,10,12,26}$

The calvaria, skull, ulnar, radi and femur bones from this investigation had shown more postmortem injuries depicting that most damage occurred after death. Postmortem damage could also be as a result of the air exposed environment which may affect the morphology and microstructure of the bones. Further findings showed that postmortem bones were very dry and brittle,which could be due to decomposition which degrades the collagen component and elasticity.

Other injuries observed from this study were sharp force,blunt force and ballistic injuries. Evidence of sharp force injuries or trauma observed among investigated bones were straight line incisions, illustrating that the injuries were from tools that were edged or pointed. Findings were not different from those of Thompson and Inglis, (2009) who reported that sharp force injuries were characterized from tools edged,pointed or bevealed with tool marks in forms of slashes (incisions wider than depth) or stabs (incisions deeper). ${ }^{27}$ They further stated that the handedness of an attacker or self-inflicted injuries could be determined by the angle of incision in context to the position of the body. ${ }^{27}$

We observed that blunt force injury was predominant in all bones. The reason could be associated with its cause which includes suicides, accidents and homicides. it has beenreferred to an injury that occurred from a low velocity impact through a blunt object or blunt surface..$^{28-29}$ Galloway,(1999) stipulated that they occurred from accidents, sticks and falls with various ranges of fractured patterns depending on both intrinsic and extrinsic factors. ${ }^{1}$ Attributes of blunt force injuries from this study were the presence of an impact area, coup, depressed, diastatic, cranial and fascial fractures. Findings were similar to Le Fort (1901), who carried out a study on 35 cadavaric skulls. ${ }^{30} \mathrm{He}$ observed three types of fractures (Le Fort I,II,III) associated with blunt force injury which he referred to as the great weak lines. ${ }^{30}$ Le Fort I was referred to a separation of the palate from the maxilla as a result of an impact to the face, Le Fort II where the maxilla was detached from the face while Fort III were the maxilla and a section of the mandibular condyles fragmented..$^{30}$ The reports of Casali et al.(2014) was also in concordance with our study. Casali et al.(2014) studied blunt force trauma among 307 victims in Milan Italy and observed that $40 \%$ of the cases showed cranial fractures while $30 \%$ displayed facial fractures. ${ }^{31}$
However findings were different from Ta'ala et al. (2006) who discovered ring and basilar fractures among 85 investigated crania of the Khmer Rouge victims, buried in mass graves at the outermost side of Phnom Penh, Cambodia between 1975 and 1979. ${ }^{32}$ Findings were also different from previous studies that observed stellate, remote, hinge and hairlinefractures associated with blunt force injury .,11,33

We observed the presence of an entrance wound, which was the most prominent feature observed among bones with ballistic injuries. Some of the ballistic bones from this study showed a circumferential and a radially branching fracture around the affected region. Several authors had linked ballistic injuries to the presence of a projectile, fractures associated with an impact from a high velocity, broken materials found within bones or the environment and entrance wounds most times smaller than exit wounds.$^{2,28-29}$ This investigation also showed that there exist a significant association between ante, peri and postmortem injuries in the ulnar, radi and femur bones. This indicates that the type of injury observed in bones are due to the mophology and microstructure of the bones.

\section{Conclusion:}

Findings from this study had shown that antemortem, perimortem and postmortem injuries were present among investigated bones. Blunt force injury was most common, hence findings will be of vital use in medicolegal investigations of deaths. Findings will also be useful to forensic anthropologist in trying to create a biological profile for an individual or group of people.

Conflicts of interest: No conflict of interest

\section{Author's contribution:}

Data gathering and idea owner of this study: Jaiyeoba-Ojigho Jennifer Efe, Odokuma Emmanuel Igho, Umukoro Joysour Mamuyovwi

Study design : Jaiyeoba-Ojigho Jennifer Efe, Odokuma Emmanuel Igho, Umukoro Joysour Mamuyovwi

Data gathering : Jaiyeoba-Ojigho Jennifer Efe, Odokuma Emmanuel Igho, Umukoro Joysour Mamuyovwi

Writing and submitting manuscript: Jaiyeoba-Ojigho Jennifer Efe, Odokuma Emmanuel Igho

Editing and approval of the final draft : JaiyeobaOjigho Jennifer Efe, Umukoro Joysour Mamuyovwi 
Jaiyeoba-Ojigho Jennifer Efe, Odokuma Emmanuel, Umukoro Joysour Mamuyovwi

\section{References:}

1. Galloway A. The biomechanics of fracture production. In: Galloway A, ed. Broken bones: anthropological analysis of blunt force trauma. Springfield, IL: Charles C.Thomas. 1999; p. 35-62

2. Smith OC, Pope EJ, Symes SA. Look until you see: identification of trauma in skeletal material. In: Steadman DW, ed. Hard evidence: case studies in forensic anthropology. Upper Saddle River, NJ: Prentice Hall. 2003; p. 138-154.

3. Hiller LP, Stover SM, Gibson VA, Gibeling JC, Prater CS, Hazelwood SJ, Yeh OC, Martin RB. Osteon pullout in the equine third metacarpal bone: effects of ex vivo fatigue. J Orthopaed Res .2003; 21:481-488.

4. White TD, Black MT, Folkens PA. Human osteology. 3rd ed. Burlington, Massachusetts: Elsevier Academic Press. 2012 .

5. Johnson E. Current developments in bone technology. In: Schiffer MB, ed. Advances in archaeological method and theory, vol. 8. Orlando: Academic Press. 1985; p. 157-235.

6. Kroman AM, Symes SA. Investigation of Skeletal Trauma. In: DiGangi EA, Moore MK.eds. Research methods in human skeletal biology.Oxford: Elsevier.2013; p. 219-240.

7. Elena FK. Forensic investigation of cranial injuries due to bluntforcetrauma:current best practice.Dove press J.,Research and reports in Forensic Med.Sc.,2015.

8. Sauer NJ. The timing of injuries and manner of death: distinguishing among antemortem, perimortem and postmortem trauma. In: Reichs KJ, ed. Forensic osteology: advances in the identification of human remains. Springfield, Illinois:Charles C Thomas. 1998; p. 321-332

9. Rodriguez-Martin C. Identification and differential diagnosis of traumatic lesions of the skeleton. In: Schmitt A, Cunha E, Pinheiro J, editors. Forensic Anthropology and Medicine: Complementary Sciences from Recovery to Cause of Death. NJ, Humana Press. 2006; 197-221.

10. Wieberg DAM, Wescott DJ. Estimating the timing of long bone fractures: correlation between the postmortem interval, bone moisture content, and bluntforce trauma fracture characteristics. J Forensic Sci. 2008;53:10281034

11. Spitz WU, Spitz DJ, Clark R. Spitz and Fisher's Medicolegal Investigation of Death: Guidelines for the Application of Pathology to Crime Investigation. 4th ed.
Springfield, IL: Charles Thomas Publisher, Ltd; 2006.

12. Symes SA, L'Abbé EN, Chapman EN, Wolff I, Dirkmaat DC. Interpreting traumatic injury to bone in medicolegal investigations. In: Dirkmaat DC editor. A Companion to Forensic Anthropology. Chichester: John Wiley \& Sons, Ltd; 2012:340-389.

13. Dedouit F, Savall F, Mokrane FZ, et al. Virtual anthropology and forensic identification using multidetector CT. Br J Radiol. 2014;87(1036)

14. Sauer NJ. Manner of death: skeletal evidence of blunt and sharp instrument wounds. In: Rathbun TA, Buikstra JE, eds. Human Identification: Case Studies in Forensic Anthropology. Springfield, IL: Charles C. Thomas, 1984, pp. 177-184.

15. Aufderheide AC, Rodriguez-Martin C. The Cambridge encyclopedia of human paleopathology. Cambridge: Cambridge University Press. 1998 .

16. Byers SN. Introduction to Forensic Anthropology: A Textbook,2nd ed. Boston, MA: Pearson Education, 2005.

17. Kostatinos M, CharaS.Identification and differenciation diagnosis of perimortem blunt force trauma in tubular long bones.Forensic Sc.Med.Pathol.,2006;2(4):221-30

18. Barbian LT, Slezik PS. Healing following cranial trauma. J Forensic Sci. 2008;53(2):263-268.

19. Villa P, Mahieu E. Breakage patterns of human long bones. J Human Evol 1991; 21:27- 48

20. Bonnichsen R. Pleistocene Bone Technology in the BeringianRefugium. National Museum of Man Mercury Series, Archaeological Survey of Canada Paper No 89. Ottawa, Canada; 1979

21. Quatrehomme G, I,scan MY. Postmortem skeletal lesions.Forensic SciInt 1997;89:155-165.

22. Walker PL. A bioarchaeological perspective on the history of violence. Annu Rev Anthropol. 2001;30:573596.

23. Marshall LG. Bone modification and "the laws of burial." In:Bonnichsen R, Sorg M, eds. Bone Modification. Orono, ME:Center for the Study of the First Americans, 1989, pp. 7- 24.

24. White TD. Prehistoric Cannibalism at Mancos 5MT UMR-2346. Princeton, NJ: Princeton University Press, 1992.

25. Jordana F, Colat-Parros J, Bénézech M. Diagnosis of skull fractures according to postmortem interval: an experimental approach in a porcine model. J Forensic Sci. 2013;58:S156-S163. 
26. Ubelaker DH, Adams BJ. Differentiation of perimortem and postmortem trauma using taphonomic indicators. $J$ Forensic Sci .,1995; 40(3):509-512.

27. Thompson TJU, Inglis J . Differentiation of serrated and non-serrated blades from stab marks in bone, Inter. $J$ of Legal Med., 2009.

28. Berryman HE, Symes SA. Recognizing gunshot and blunt cranial trauma through fracture interpretation. In: Reichs KJ, editor. Forensic Osteology: Advances in the Identification of Human Remains. Springfield, IL: Charles C. Thomas; 1998:333-352

29. Smith OC, Pope EJ, Symes SA. Look until you see: identification of trauma in skeletal material. In: Steadman DW, ed. Hard evidence: case studies in forensic anthropology. Upper Saddle River, NJ: Prentice Hall. 2003; p. 138-154.

30. Le Fort R. Experimental study on fractures of the upper jaw. Revue chir de Paris. 1901;23:208-227, 360-379, 479-507.

31. Casali MB, Battistini A, Blandino A, Cattaneo C. The injury pattern in fatal suicidal falls from a height: an examination of 307 cases. Forensic Sci Int . 2014;244:5762.

32. Ta'ala, SC, Berg, GE, Haden, K. Blunt force cranial trauma in the cambodian killing fields. Forensic Sci Int. 2006;51:996-1001.

33. Di Maio VJM, Di Maio D. Forensic Pathology. 2nd ed. Boca Raton, FL: CRC Press; 2001 